\title{
WATER RELATIONS AT THE INITIAL SUGARCANE GROWTH PHASE UNDER VARIABLE WATER DEFICIT
}

Doi:http://dx.doi.org/10.1590/1809-4430-Eng.Agric.v37n2p268-276/2017

\section{ROBSON MAURI ${ }^{*}$, RUBENS D. COELHO ${ }^{2}$, EUSÍMIO F. FRAGA JUNIOR ${ }^{3}$, FERNANDO DA S. BARBOSA ${ }^{4}$, DANIEL P. V. LEAL ${ }^{5}$}

${ }^{1 *}$ Corresponding author. Escola Superior de Agricultura "Luiz de Queiroz" / ESALQ - Universidade de São Paulo/ USP, Piracicaba-SP, Brasil. E-mail: rmauri.agro@gmail.com

\begin{abstract}
This study aimed to quantify water deficit levels that compromise sugarcane initial growth exposed to different availability soil depths. The experiment was conducted in a greenhouse by using 100-liter capacity asbestos-cement boxes filled with different soil layers simulating depths of $10,20,30$, and $40 \mathrm{~cm}$. Water deficit levels were represented by accumulated reference evapotranspiration of $0,40,80,120,160,200,240$, and $280 \mathrm{~mm}$, which was considered from planting to irrigation return. Soil moisture at field capacity at planting time was sufficient to promote sprouting and emergence regardless the water deficit level that was subsequently exposed. For soil depths of 10 and $20 \mathrm{~cm}$, a 160-mm water deficit level caused total plant death. On the other hand, for soil depths of 30 and $40 \mathrm{~cm}$, a $200-\mathrm{mm}$ water deficit level promoted plant death. A water deficit level from $40 \mathrm{~mm}$ significantly reduced plant growth regardless soil depth.
\end{abstract}

KEYWORDS: irrigation, sprouting, Saccharum spp., growth.

\section{INTRODUCTION}

Brazil is the world's largest exporter of sugar and the country that most uses ethanol as a source of renewable energy. Discussions on global warming and alternative energy sources have stimulated the use of ethanol. The increase in demand, in turn, boosted the expansion of sugarcane plantations in Brazil, especially in the states of São Paulo, Mato Grosso do Sul, Goiás, and Minas Gerais. However, this expansion has often occurred in areas less favorable to crop development, especially when considering soil water availability, which derives from a poor rainfall distribution in these regions.

A restrictive soil water availability adversely affects agricultural crop growth and it is one of the main causes of reduced productivity. In this sense, initial growth phase of plant cane is the period most sensitive to water deficit (TRENTIN et al., 2011).

Water has a prominent position in the agricultural production and its low availability reduces productivity, even in the most fertile soils. Regardless the crop, water is a limiting factor when searching the maximum expression of productive potential, as it affects plant growth, reduces agricultural productivity, and results in low efficiency of its use by the crops and fertilizers. In a sugarcane plant, water represents about $71 \%$ of its fresh weight (DALRI \& CRUZ, 2008; GONÇALVES et al., 2010).

Sugarcane initial growth occurs during sprouting and beginning of tillering phases. Sprouting is a critical event in the crop cycle, being dependent on water and nutrient concentration in the stalk, bud's age, soil moisture, and root system development, which undergoes soil compaction influence (BULL \& GLASZIOU, 1975; NASSIF, 2010; TOMER, 1969).

Soil moisture is not the main factor that influences plant cane sprouting via a stalk (traditional), but germination decreases as soil moisture decreases, as observed by MOREIRA \& CARDOSO (1998). However, there is little information about water restriction that occurred after

\footnotetext{
${ }^{2}$ Escola Superior de Agricultura "Luiz de Queiroz" / ESALQ - Universidade de São Paulo/ USP, Piracicaba-SP, Brasil.

${ }^{3}$ Universidade Federal de Uberlândia/ UFU - Campus Monte Carmelo, Monte Carmelo-MG, Brasil.

${ }^{4}$ Instituto Federal do Sul de Minas/ IFSuldeMinas - Campus Inconfidentes, Inconfidentes-MG, Brasil.

${ }^{5}$ Faculdades Associadas de Uberaba/ FAZU, Uberaba-MG, Brasil.

Received in: 9-30-2013
}

Accepted in: 1-10-2017 
sprouting. BARBOSA et al. (2014) studied the varieties RB867515 and SP81-3250, during initial growth; these authors observed that, once available, soil water withers easily, proving that these varieties have a relatively low drought resistance. However, little information is available on deficit level that sugarcane plants support. Such information could not only guarantee the stand but also generate water savings.

Water deficit limits sugarcane production, especially in regions where a prolonged dry season occurs, such as in the Midwest Region of Brazil (SILVA et al., 2008a; SILVA et al., 2008b). In these regions, and even in regions with good water availability but subject to dry spells, the use of irrigation is essential to obtain a minimum satisfactory production. OLIVEIRA et al. (2011) showed that the use of irrigation promotes an increase in productivity of stalks and sugar, improves water use efficiency, and sugar/fiber ratio, which indicates a technical viability of this management as an alternative to increasing Brazilian sugarcane plantations productivity.

In general, several authors, such as INMAN-BAMBER (2004), PIMENTEL (2004), COELHO (2012), have mentioned the sugarcane canopy and productivity reduction when the water supply is limited. However, there is little knowledge on water restriction and its effects on sugarcane growth, especially at the initial phase. This information makes it possible to recommend sugarcane planting ideal periods as a function of rainfall distribution, as well as to recommend a possible "rescue irrigation" during dry spell periods without affecting significantly initial crop growth and, consequently, final production. Based on the hypothesis that sugarcane initial growth has no significant reduction until a certain level of water deficit, this study aimed to quantify such amount for sugarcane plants grown at different available soil water depths.

\section{MATERIAL AND METHODS}

This study was carried out from February 8 to May 5 of 2011. Trials were conducted in a greenhouse installed at the research area of the Department of Biosystems Engineering of the Luiz de Queiroz School of Agriculture (ESALQ/USP), Piracicaba, SP, Brazil. The area is located at the geographical coordinates $22^{\circ} 42^{\prime} 32^{\prime \prime} \mathrm{S}$ and $47^{\circ} 37^{\prime} 45^{\prime \prime} \mathrm{W}$, with an average altitude of $548 \mathrm{~m}$. According to Köppen climate classification, local climate is humid subtropical mesothermic type Cwa, with three months drier (June, July, and August), characterized by a rainy summer and a dry winter. The average temperature of the warmest month is above $22{ }^{\circ} \mathrm{C}$ and below $18{ }^{\circ} \mathrm{C}$ in the coldest month.

The greenhouse was installed following the east-west orientation and presented a transparent polyethylene plastic film coverage with a $150-\mu \mathrm{m}$ thickness and sides closed with a sombrite-type screen with a $30 \%$ solar radiation interception. In a useful area of $160 \mathrm{~m}^{2}, 96$ asbestos-cement boxes with a capacity of $100 \mathrm{~L}$ and dimensions of $60 \times 40 \times 45 \mathrm{~cm}$ were distributed and arranged in four strips spaced $80 \mathrm{~cm}$ between rows and $50 \mathrm{~cm}$ between boxes, distanced $100 \mathrm{~cm}$ from the greenhouse sides. Soil used to fill the boxes is classified as a sandy loam-textured Oxisol, Sertãozinho Series. Tables 1 and 2 display the soil chemical and physical-hydric characteristics in the four studied layers, respectively.

TABLE 1. Soil chemical characterization.

\begin{tabular}{|c|c|c|c|c|c|c|c|c|c|c|c|c|}
\hline \multirow{2}{*}{\multicolumn{3}{|c|}{$\begin{array}{l}\text { Layer } \mathrm{pH} \\
(\mathrm{cm}) \mathrm{CaCl}_{2}\left(\mathrm{~g} \mathrm{dm}^{-3}\right)\end{array}$}} & $\mathrm{P}$ & $\mathrm{S}$ & $\mathrm{K}$ & $\mathrm{Ca}$ & $\mathrm{Mg}$ & $\mathrm{Al}$ & $\mathrm{H}+\mathrm{Al}$ & SB & CEC & \multirow{2}{*}{$\begin{array}{l}\mathrm{BS} \\
\% \\
\end{array}$} \\
\hline & & & -----(mg dm- & 3) ----- & $---\cdot$ & - & - & $(\mathrm{mm}$ & $\left.n^{-3}\right)-$ & 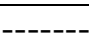 & ------ & \\
\hline $0-10$ & 5.43 & 12 & 49 & 50 & 1.1 & 20 & 2 & 0.01 & 21 & 23.1 & 43.7 & \\
\hline $0-20$ & 5.66 & 12 & 56 & 28 & 0.7 & 25 & 2 & 0.01 & 19 & 27.7 & 46.3 & \\
\hline $0-30$ & 5.69 & 12 & 53 & 24 & 0.5 & 22 & 2 & 0.01 & 18 & 24.5 & 42.9 & \\
\hline $0-40$ & 5.63 & 21 & 64 & 20 & 0.7 & 24 & 3 & 0.01 & 19 & 27.7 & 46.7 & 59 \\
\hline
\end{tabular}

SOM: soil organic matter; SB: sum of bases; CEC: cation exchange capacity; BS: base saturation. 
TABLE 2. Soil physical-hydric characterization.

\begin{tabular}{|c|c|c|c|c|c|c|c|c|c|}
\hline \multirow{3}{*}{$\begin{array}{c}\text { Layer } \\
(\mathrm{cm})\end{array}$} & $\mathrm{FC}$ & PWP & \multirow{3}{*}{$\begin{array}{l}\text { AWC } \\
(\mathrm{mm})\end{array}$} & $\mathrm{D}$ & $\mathrm{D}$ & \multirow{3}{*}{$\begin{array}{c}\mathrm{TP} \\
(\%)\end{array}$} & \multicolumn{3}{|c|}{ Texture fraction } \\
\hline & $\mathrm{FC}$ & & & $\mathrm{D}_{\mathrm{s}}$ & $D_{p}$ & & Sand & Silt & Clay \\
\hline & \multicolumn{2}{|c|}{$\mathrm{g} \mathrm{g}^{-1}$} & & \multicolumn{2}{|c|}{$\mathrm{g} \mathrm{cm}^{-3}$} & & & $\%$ & \\
\hline $0-10$ & 0.148 & 0.069 & 12.11 & 1.53 & 2.65 & 42.3 & 75.1 & 7.8 & 17.1 \\
\hline $10-20$ & 0.151 & 0.065 & 12.81 & 1.50 & 2.65 & 43.4 & 74.5 & 8.0 & 17.5 \\
\hline $20-30$ & 0.151 & 0.065 & 12.81 & 1.50 & 2.65 & 43.4 & 74.5 & 8.0 & 17.5 \\
\hline $30-40$ & 0.143 & 0.078 & 10.88 & 1.69 & 2.64 & 36.0 & 74.4 & 8.6 & 17.0 \\
\hline
\end{tabular}

FC: field capacity moisture (corresponding to a matric potential $\psi_{\mathrm{m}}$ of $-4.85 \mathrm{kPa}$ ); PWP: permanent wilting point moisture (corresponding to a matric potential $\psi_{\mathrm{m}}$ of $-1500 \mathrm{kPa}$ ); AWC: available water capacity; $\mathrm{D}_{\mathrm{s}}$ : soil density; $\mathrm{D}_{\mathrm{p}}$ : soil particle density; TP: total soil porosity.

Treatments consisted of a combination of four soil depths and eight water deficit levels. These depths aimed to simulate environments in which sugarcane will have soil availability restrictions, which is commonly found in regions with shallow or compacted soils. Compacted soils in general present greater resistance to root penetration, which causes a reduction in the effective depth of root system, reducing the water available to plants.

As previously mentioned, all boxes presented a depth of $40 \mathrm{~cm}$ and each set of 24 boxes were filled with different soil layers simulating depths of 10,20,30, and $40 \mathrm{~cm}$ of available soil. In order to reach this soil availability, the boxes were filled with different layers of gravel \#2, composing layers of 10, 20, 30, and $40 \mathrm{~cm}$, named as D10, D20, D30, and D40, respectively. For instance, in treatment D10, $30 \mathrm{~cm}$ of a box was filled with gravel \#2 and $10 \mathrm{~cm}$ with soil. A geotextile fabric was used to separate the gravel from soil layers. Available water capacity (AWC) values for treatments D10, D20, D30, and D40 were 12.11, 24.92, 37.73, and $48.61 \mathrm{~mm}$, respectively.

Water deficit levels were represented by accumulated reference evapotranspiration $\left(\mathrm{ET} 0_{\mathrm{ac}}\right)$ with values of $0,40,80,120,160,200,240$, and $280 \mathrm{~mm}$ accumulated from planting to a new irrigation of treatment, being named N0, N40, N80, N120, N160, N200, N240, and N280, respectively. Immediately after planting, soil moisture was increased to field capacity in all treatments, starting ET0 $\mathrm{ac}_{\mathrm{ac}}$ counting the next day. Thus, for plants of the treatment N0, irrigation was maintained, being suspended in the other treatments until the pre-established $\mathrm{ETO}_{\mathrm{ac}}$ level for each treatment was reached. After reaching this level, irrigation was started and maintained until the experiment has ended. Irrigation system used was the drip irrigation with pressure-compensating dripper (PCJ-CNL).

The experimental design was randomized block design in a $4 \times 8$ factorial scheme with three replications (blocks), totaling 96 experimental units represented by a 100-L asbestos-cement box. Initially, each box contained six sugarcane buds. The resulting average values of these plants were used in the statistical analysis. The variety used was RB867515, widely cultivated in Brazil, especially in the state of São Paulo.

Meteorological data were collected every 30 seconds and integrated every 15 minutes by means of a data acquisition system (Campbell CR1000). Radiation balance $\left(R_{n}\right)$ was estimated from the global solar radiation, monitored with a pyranometer (LP02-L12, Campbell Sci). A Vaisala sensor (HMP45CL12, Campbell Sci.) was used to measure relative humidity and air temperature. Sensors were installed $2 \mathrm{~m}$ high inside the greenhouse's center. The Penman-Monteith model proposed by ALLEN et al. (1998) estimated reference evapotranspiration (ETo). Because wind speed inside the greenhouse was very low, this value was set at $0.5 \mathrm{~m} \mathrm{~s}^{-1}$, according to FAO Bulletin 56 (ALLEN et al., 1998).

For irrigation management, puncture tensiometers were installed at different depths according to treatments: at $5 \mathrm{~cm}$ depth for treatment P10; at 5 and $15 \mathrm{~cm}$ for treatment P20; at 5, 15, and 25 $\mathrm{cm}$ for treatment P30; and at 5, 15, 25, and $35 \mathrm{~cm}$ for treatment P40. The depth was considered as the distance from the soil surface to the center of the porous capsule. Tensiometer readings were performed within a range of 2 to 3 days by using a digital tensiometer so that the matric potential of soil water for the treatments that were being irrigated did not exceed $-30 \mathrm{kPa}$. Matric potential 
measured by each tensiometer was considered as representing the average matric potential of a 10$\mathrm{cm}$ layer, i.e. the measurements of tensiometers installed at 5, 15, 25, and $35 \mathrm{~cm}$ represented moisture layers from 0 to 10,10 to 20,20 to 30 , and 30 to $40 \mathrm{~cm}$, respectively.

Soil moisture was estimated by the VAN GENUCHTEN (1980) equation from tensiometer readings. After estimating soil moisture values, water volume required to raise soil moisture to field capacity was calculated for the corresponding reading layer. For treatments P20, P30, and P40, the sum of volumes of each layer corresponded to the total volume applied in the box.

Soil moisture monitoring was performed in one of the three boxes of each treatment. Water volumes applied in the other two boxes were the same as the monitored box. At the end of the experiment, soil moisture was raised to field capacity in all treatments, allowing quantifying the total volume of water applied. For treatments from N80, some soil depths reached low moisture levels, with matric potential reaching values lower than $-90 \mathrm{kPa}$, not being possible to estimate moisture by tensiometry. Thus, when ETO $_{\mathrm{ac}}$ level was reached and before starting/returning irrigation, soil samples were collected for moisture quantification by gravimetric method (standard oven method).

Irrigation return was performed after pre-established $\mathrm{ETO}_{\mathrm{ac}}$ accumulation. For this, the moisture of the moment was raised to field capacity. This methodology was possible to be used up to the level N40. From N80, soil moisture value was not known since its estimation was not possible by means of tensiometry and the gravimetric determination was not immediate. Thus, $80 \%$ of available water capacity was applied, tensiometers were subsequently primed, and the next day soil moisture was raised to field capacity. For all treatments, the number of emerged buds was counted every week, being considered only those that sprouted and reached the soil surface.

After irrigation return of each treatment, the percentage of plants that survived was assessed according to water deficit levels. A visual analysis of all plants was carried out for a period of approximately 10 days in order to confirm their death. Visual analysis was performed observing the base of the leaf roll; when these leaves restarted the development, plants were considered as alive.

The experiment was finished after 90 days and plants were collected for dry matter analysis. The material was collected separately for dry matter quantification of the primary stalk and dry matter of other tillers. After collecting procedure, the material was taken to an oven with a forced hot air circulation system at a temperature of $65{ }^{\circ} \mathrm{C}$ until constant mass, which occurred after 72 hours. Mass was measured in a semi-analytical digital balance with an accuracy of $0.01 \mathrm{~g}$.

The variables assessed during the experimental period were analyzed using the free software $\mathrm{R}$, version 2.13 (R DEVELOPMENT CORE TEAM, 2011), in which was carried out the analysis of variance and the Tukey's test at $5 \%$ probability level.

\section{RESULTS AND DISCUSSION}

The experiment was conducted from February 8 to May 9, 2011, totaling 90 days. Water deficit and the respective accumulated ET0 $\left(\mathrm{ETO}_{\mathrm{ac}}\right)$ levels during treatments implementation are presented in Table 3.

TABLE 3. Dates of irrigation return after water deficit period as a function of accumulated ET0.

\begin{tabular}{cccccc}
\hline \multirow{2}{*}{ Treatment } & \multirow{2}{*}{ Irrigation return } & \multicolumn{2}{c}{ Interval } & \multicolumn{2}{c}{ Total accumulated } \\
\cline { 3 - 6 } & & Day & ET0 $(\mathrm{mm})$ & Day & ET0 $(\mathrm{mm})$ \\
\hline N0 & $02 / 09 / 2011$ & 1 & 3.81 & 1 & 3.81 \\
N40 & $02 / 21 / 2011$ & 12 & 42.24 & 12 & 42.24 \\
N80 & $03 / 09 / 2011$ & 16 & 39.08 & 28 & 81.32 \\
N120 & $03 / 25 / 2011$ & 16 & 40.13 & 44 & 121.46 \\
N160 & $04 / 10 / 2011$ & 16 & 40.66 & 60 & 162.11 \\
N200 & $04 / 26 / 2011$ & 16 & 39.46 & 76 & 201.57 \\
\hline
\end{tabular}


Treatments N0, N40, N80, N120, N160, and N200 refer to estimated ET0 data of 3.81, 42.24, $81.32,121.46,162.11$, and $201.57 \mathrm{~mm}$, respectively. These values were estimated by the PenmanMonteith equation and accumulated (summed) day by day. The treatment of water deficit N200 was sufficient to promote the death of all plants regardless soil depth, as will be discussed later. Thus, the experiment was concluded 14 days after irrigation return in the treatment N200, not being necessary to obtain the values for N240 and N280 since all plants were already dead in these treatments, i.e. at the same condition as in the treatment N200.

Meteorological data variation during the experiment is presented in Figure 1. In the treatment N40, ET0 values were higher, resulting in an interval with a lower number of days for irrigation return (12 days). During this period, the highest values of temperature and solar radiation and the lowest values of average relative humidity were recorded inside the greenhouse. For the other treatments, these variations remained similar, resulting in longer time intervals (16 days).

The highest ET0 value was observed at 4 DAP $\left(4.12 \mathrm{~mm} \mathrm{day}^{-1}\right)$ when the highest amount of radiant energy (16.31 $\mathrm{MJ} \mathrm{m}^{-2} \mathrm{day}^{-1}$ ) also occurred. The minimum ET0 value (1.09 $\left.\mathrm{mm} \mathrm{day}^{-1}\right)$ occurred at 54 DAP, with the lowest radiant energy value $\left(2.7 \mathrm{MJ} \mathrm{m}^{-2} \mathrm{day}^{-1}\right)$ recorded in this period since solar radiation is a variable with the highest effect on ET0 value estimation (ALLEN et al., 1998).

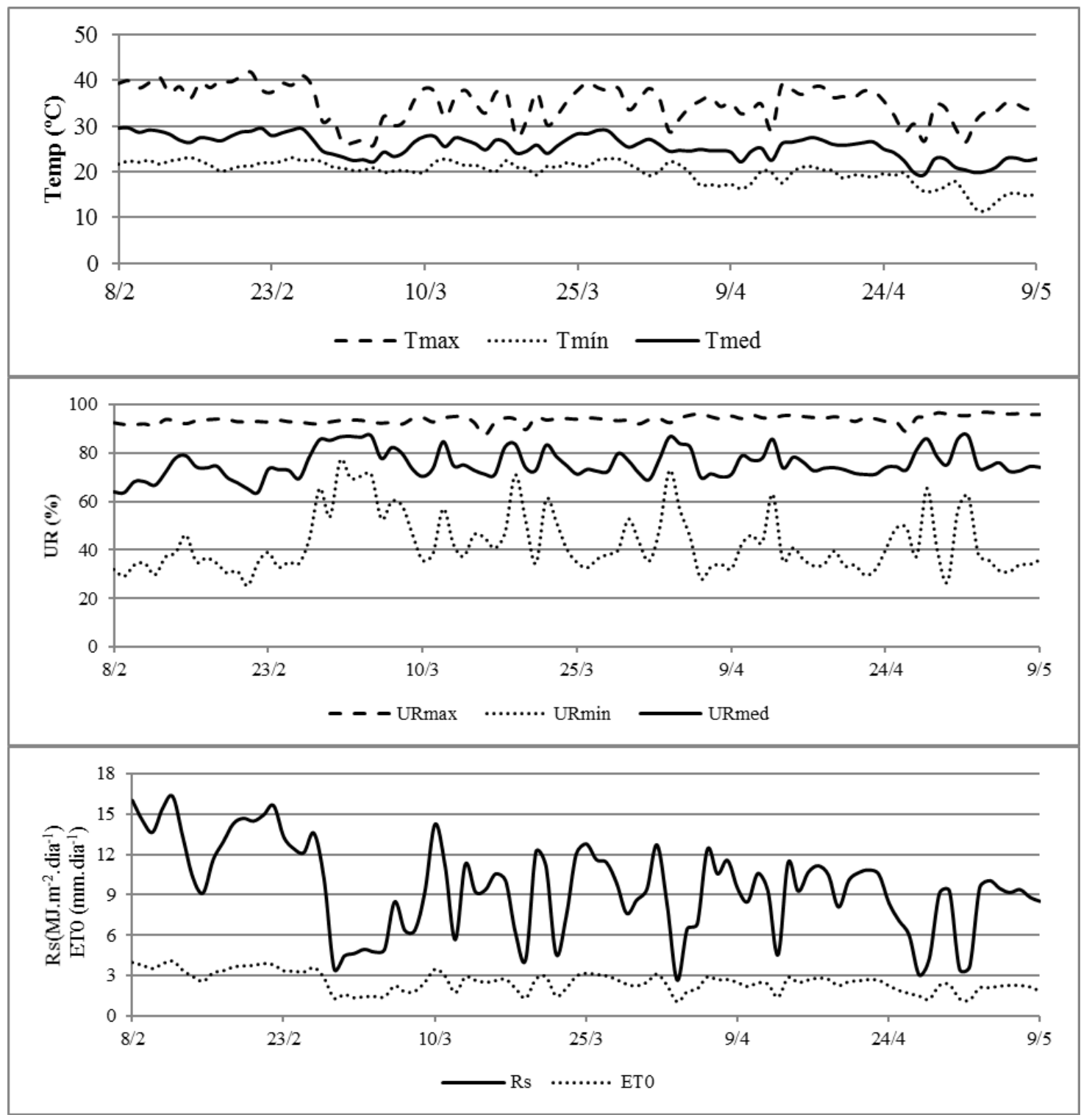

FIGURE 1. Daily variation of maximum (Tmax), minimum (Tmin), and average (Tavg) temperature, maximum (RHmax), minimum (RHmin), and average (RHavg) relative humidity, solar radiation (SR), and reference evapotranspiration (ET0). 
In the first $15 \mathrm{DAP}$, the average temperature was $28.31{ }^{\circ} \mathrm{C}$, which was higher than the average registered for the period, favoring sprouting, and emergence. The analysis of variance for this variable showed that the studied factors act independently, with no significant interaction between them. Regarding the effects of each treatment, water deficit levels did not influence bud sprouting and tiller emergence, indicating that the initial moisture at field capacity is enough to promote swelling and start physiological processes of shoot emergence (Table 4). These results suggest the need for an eventual irrigation close to the planting time if it is carried out in periods of low precipitation or during dry spell periods.

TABLE 4. Analysis of average bud sprouting at 60 DAP for different water deficit levels.

\begin{tabular}{lcccccc}
\hline Treatment & N0 & N40 & N80 & N120 & N160 & N200 \\
\hline Bud sprouting (\%) & 79.17 & 79.17 & 76.39 & 81.94 & 83.33 & 79.17 \\
\hline
\end{tabular}

* The means of this factor are statistically equal according to the F-test at $5 \%$ probability.

An influence was observed on the effect of soil depth, which presented significantly lower values of sprouting and emergence at the depth D10, shallower soil (Table 5). Reinforcing this result, VASCONCELLOS \& CASAGRANDE (2010) cite that the presence of compacted layers prevents or reduces root growth toward deeper layers and results in a more superficial root system, making sprouting and growth processes less favorable.

TABLE 5. Analysis of average tiller emergence at 60 DAP for different soil depths.

\begin{tabular}{lcccc}
\hline Treatment & D10 & D20 & D30 & D40 \\
\hline Tiller Emergence $(\%)$ & $68.51 \mathrm{~b}$ & $82.40 \mathrm{a}$ & $85.18 \mathrm{a}$ & $83.33 \mathrm{a}$ \\
\hline Means followed by the same letter do not differ by the Tukey's test with a nominal significance level $(\alpha)$ of $5 \%$ &
\end{tabular}

Water deficit levels that caused plant death varied significantly as a function of soil depth. For a depth of $10 \mathrm{~cm}$, from $80 \mathrm{~mm} \mathrm{ET0} 0_{\mathrm{ac}}, 10.8 \%$ of plants had already died as in the other depths this water deficit level did not cause a reduction in the number of live clumps (plant population). Through linear interpolation of values, the percentage of live clumps was estimated for smaller ET0 $0_{\mathrm{ac}}$ intervals at different soil depths, as shown in Table 6.

TABLE 6. Estimated percentage of live clumps at the depths D10, D20, D30, and D40 (AWC of $12.11,24.92,37.73$, and $48.61 \mathrm{~mm}$, respectively) as a function of water deficit $\left(\mathrm{ETO}_{\mathrm{ac}}\right)$.

\begin{tabular}{|c|c|c|c|c|c|c|c|c|c|c|c|c|c|}
\hline \multirow{2}{*}{ Soil depth } & \multicolumn{13}{|c|}{ Accumulated ET0 (mm) } \\
\hline & 80 & 90 & 100 & 110 & 120 & 130 & 140 & 150 & 160 & 170 & 180 & 190 & 200 \\
\hline D10 & 89.2 & 75.5 & 61.8 & 48.1 & 34.4 & 25.8 & 17.2 & 8.6 & 0.0 & 0.0 & 0.0 & 0.0 & 0.0 \\
\hline D20 & 100 & 96.9 & 93.9 & 90.8 & 87.8 & 65.8 & 43.9 & 21.9 & 0.0 & 0.0 & 0.0 & 0.0 & 0.0 \\
\hline D30 & 100 & 100 & 100 & 100 & 100 & 76.4 & 52.8 & 29.2 & 5.6 & 4.2 & 2.8 & 1.4 & 0.0 \\
\hline D40 & 100 & 100 & 100 & 100 & 100 & 83.2 & 66.5 & 49.7 & 33.0 & 24.8 & 16.5 & 8.2 & 0.0 \\
\hline
\end{tabular}

According to Stolf (1986), failures in sugarcane planting rows between 30 and $50 \mathrm{~cm}$, i.e. between 70 and $50 \%$ of live plants in the row, do not always affect the final quality stand since under these conditions tillering can be stimulated by a higher solar radiation, which ends up compensating the final number of stalks in the crop. However, according to this methodology, from $50 \%$ failures, it is recommended to replant the area.

A $200-\mathrm{mm} \mathrm{ET0} 0_{\mathrm{ac}}$ water deficit level caused a $100 \%$ plant mortality at all studied depths (Table 6). From $80 \mathrm{~mm} \mathrm{ET0}$ ac, soil moisture was below the permanent wilting point for all depths, with lower depths showing levels that are more critical. According to TAIZ \& ZEIGER (2004), after soil reaches these moisture values, water release to the roots is slow since soil resistance to water flow is great, which does not allow recovering the nocturnal turgescence of plants that withered during the day. This suggests that the live clump maintenance for a relatively long period in soils with very low moisture contents is due to stalk reserves, which suggests the importance of 
using good quality seedlings.

A resistance in the plant later hampers this turgescence recovery, which is much greater than that in the soil. After drying, plant cells shrink. When roots shrink, their surface can move away from soil particles that retain water; in this case, the delicate root hairs may be damaged. In addition, because roots expand slowly during desiccation, their outer cortex layer often becomes extensively covered by suberin, a water-impermeable lipid that increases the resistance to water flow (TAIZ \& ZEIGER, 2004).

For this variable, a significant effect was observed by the $\mathrm{F}$ test with an interaction between water deficit levels and soil depth for both primary stalk and clump (primary stalk + tillers). An increase in water deficit levels and a reduction in soil depth caused a significant reduction in dry matter accumulation of the primary stalk and plant clump (Tables 7 and 8).

TABLE 7. Analysis of averages related to dry matter accumulation (g) of the main stalk as a function of water deficit level and soil depth at 90 DAP.

\begin{tabular}{lcccccc}
\hline Treatment & $\mathrm{N} 0$ & $\mathrm{~N} 40$ & $\mathrm{~N} 80$ & $\mathrm{~N} 120$ & $\mathrm{~N} 160$ & $\mathrm{~N} 200$ \\
\hline D10 & $21.94 \mathrm{Ac}$ & $19.87 \mathrm{Ab}$ & $3.92 \mathrm{Bd}$ & $0.86 \mathrm{Bc}$ & $0.36 \mathrm{Bb}$ & $0.60 \mathrm{Bb}$ \\
D20 & $28.63 \mathrm{Ab}$ & $22.86 \mathrm{Bb}$ & $14.43 \mathrm{Cc}$ & $5.54 \mathrm{Db}$ & $1.08 \mathrm{~Eb}$ & $1.75 \mathrm{DEab}$ \\
D30 & $29.94 \mathrm{Ab}$ & $28.57 \mathrm{Aa}$ & $21.46 \mathrm{Bb}$ & $19.96 \mathrm{Ba}$ & $3.66 \mathrm{Cab}$ & $2.44 \mathrm{Cab}$ \\
D40 & $41.83 \mathrm{Aa}$ & $29.53 \mathrm{Ba}$ & $25.99 \mathrm{Ba}$ & $20.98 \mathrm{Ca}$ & $4.72 \mathrm{Da}$ & $4.48 \mathrm{Da}$ \\
\hline
\end{tabular}

Means followed by the same uppercase letter in a row and lowercase letter in a column do not differ by the Tukey's test with a significance level $(\alpha)$ of $5 \%$.

TABLE 8. Analysis of averages related to dry matter accumulation (g) of clump (primary stalk + tillers) as a function of water deficit level and soil depth at 90 DAP.

\begin{tabular}{lcccccc}
\hline Treatment & $\mathrm{N} 0$ & $\mathrm{~N} 40$ & $\mathrm{~N} 80$ & $\mathrm{~N} 120$ & $\mathrm{~N} 160$ & $\mathrm{~N} 200$ \\
\hline D10 & $22.50 \mathrm{Ad}$ & $20.92 \mathrm{Ac}$ & $5.20 \mathrm{Bc}$ & $0.89 \mathrm{Bc}$ & $0.36 \mathrm{Ba}$ & $0.62 \mathrm{Ba}$ \\
D20 & $30.83 \mathrm{Ac}$ & $25.95 \mathrm{Ab}$ & $17.07 \mathrm{Bb}$ & $5.94 \mathrm{Cb}$ & $1.08 \mathrm{Ca}$ & $1.75 \mathrm{Ca}$ \\
D30 & $45.32 \mathrm{Ab}$ & $32.64 \mathrm{Ba}$ & $28.69 \mathrm{BCa}$ & $25.80 \mathrm{Ca}$ & $3.79 \mathrm{Da}$ & $2.53 \mathrm{Da}$ \\
D40 & $63.43 \mathrm{Aa}$ & $34.29 \mathrm{Ba}$ & $32.10 \mathrm{Ba}$ & $23.40 \mathrm{Ca}$ & $4.85 \mathrm{Da}$ & $5.34 \mathrm{Da}$ \\
\hline
\end{tabular}

Means followed by the same uppercase letter in a row and lowercase letter in a column do not differ by the Tukey's test with a significance level $(\alpha)$ of $5 \%$.

The lower amount of dry matter accumulated in the aerial part due to water deficit can be attributed to a reduction in the area of radiation interception, caused by a reduction in leaf size as a plant attempt in reducing transpiration and maintaining water content in the cells, avoiding paralyzing physiological processes. The decrease in leaf size also occurs as a function of a decrease in pressure potential. MARQUES et al. (2013) observed that there is an interaction between increased water availability and plant physiology, leading to increased vegetative growth and sprouting.

Dry matter reduction observed as soil depth decreased is due to a lower soil volume explored by root system and lower soil moisture levels found at these depths. These results are in accordance with BARAN et al. (1974), who explained that sugarcane production would be economically more viable in a medium fertility soil with high water availability. Such condition allows root depth development if compared to a high fertility soil with low water availability, which promotes little root system growth in depth, being thus concentrated within the surface layers.

In general, an economic production of sugarcane is given by the quantity and quality of raw material at the end of the whole cycle, which is a response to all processes involved during production system. The initial crop phase is already responsible for a certain production potential since obtaining a higher productivity depends on a good initial crop growth and tillering. Thus, a soil management wherein plants could find good soil chemical and physical conditions; for example 
in D40, RB867515 variety was very responsive to irrigation during initial growth phase, presenting the highest values of dry matter accumulated for both main stalk (Table 7) and dry matter of clump (Table 8) for the treatment without water restriction (N0).

Still considering dry matter accumulation presented in Tables 7 and 8, this variety, in addition to being responsive to irrigation, presents sensitivity characteristics to water deficit. Even under favorable soil management conditions (D40), dry matter production of both main tiller and clump were drastically reduced under the first level of water deficit (N40). The accumulated dry matter value of the main tiller was reduced to $70.6 \%$ of the value observed for the treatment without water deficit (N0), being this reduction even greater for clump, reaching a reduction of $54.1 \%$ of the value observed for the treatment without water deficit (N0).

Thus, in general, when sugarcane growth occurs in unfavorable soil management scenarios (treatments D10 and D20), even if maintained a good water availability (treatment N0), a significant reduction in plant growth occurs, with a drastic reduction of accumulated dry matter (Table 8). Therefore, irrigation technique does not work in isolation but must be associated with other crop management practices. Likewise, under these unfavorable conditions, the negative effect of water deficit on plant growth is even greater since the incipient root system at this crop stage does not allow the use of water from the whole soil profile, causing a significant reduction in plant growth and development when submitted to water deficit.

\section{CONCLUSIONS}

In quantitative terms, water deficit accumulated during the initial growth phase, have no influence on bud sprouting and tiller emergence (excepted for D10 treatment) under the condition that soil moisture is at field capacity at bud planting time.

Sugarcane RB867515 variety is very responsive to irrigation but also very sensitive to water deficit. Water deficit values corresponding to $40 \mathrm{~mm} \mathrm{ET0} 0_{\mathrm{ac}}$ are already sufficient to reduce significantly plant growth and dry mass accumulation, specially for the soil depths considered in this experiment.

\section{REFERENCES}

ALLEN, R.G.; PEREIRA, L.S.; RAES, D.; SMITH, D. Crop evapotranspiration: guides for computing crop water requirements Food and Agriculture Organization of the United Nations FAO. Rome, 1998. 300 p. (FAO Irrigation and Drainage Paper, 56).

BARAN, R.; BASSEREAU, D.; GILLET, N. Measurement of available water and root development on an irrigated sugar cane crop in the Ivory Coast. In: CONGRESS OF THE INTERNATIONAL SOCIETY OF SUGAR CANE TECHNOLOGISTS, 15., 1974, Durban. Proceedings... Durban: Hayne \& Gibson, 1974. v. 2. p.726-735.

BARBOSA, F. S.; COELHO. R.D.; MASCHIO, R.; LIMA, C. J.G.S.; SILVA, E. M .da.; Drought resistance of sugar-cane crop for different levels of water availability in the soil. Engenharia Agrícola, Jaboticabal, v. 34, n.2, p. 203-210, mar./abr. 2014, Disponível em:

<http://www.scielo.br/scielo.php?pid=S0100-69162014000200002\&script=sci_arttext >. Acesso em: 12 maio 2015. DOI: 10.1590/S0100-69162014000200002.

BULL, T. A.; GLASZIOU, K. T. Sugar cane. In: EVANS, L. T. (Ed.). Crop physiology: Some case histories. Cambridge: University Press, 1975. cap. 3, p.51-72.

COELHO, R. D.; MASCHIO, R.; LEAL, D. P. V.; BARBOSA, F. S.; MAURI, R.. Water Productivity into Biomass and Energy for 24 Brazilian Sugarcane Varieties Under Drip Irrigation. In: ASABE 2012 - Annual International Meeting, 2012, Dallas. Anais... St. Joseph: ASABE, 2012. v. 1, 2012. CD-ROM.

DALRI, A.B.; CRUZ, R.L. Produtividade da cana-de-açúcar fertirrigada com N e K via gotejamento subsuperficial. Engenharia Agrícola, Jaboticabal, v.28, n.3, p.516-524, 2008. 
GONÇALVES, E.R.; FERREIRA, V.M.; SILVA, J.V.; ENDRES, L.; BARBOSA, T.P.; DUARTE, W.G.de. Trocas gasosas e fluorescência da clorofila a em variedades de cana de açúcar submetidas á deficiência hídrica. Revista Brasileira de Engenharia Agrícola e Ambiental, Campina Grande, v.14, n.4, p.378-386, 2010.

INMAN-BAMBER, N.G. Sugarcane water stress criteria for irrigation and drying off. Field Crops Research, Amsterdam, v. 89, p. 107-122, 2004.

MARQUES, T. A.; MARQUES, P. A. A.; SURIANI, M. W.; SANTOS, ARLETO T.; MENDONÇA, F. C. Water absorbent polymer in sugarcane crop. Engenharia Agrícola, Jaboticabal, v. 33, n. 1, p. 99-108, 2013.

MOREIRA, D. R. , CARDOSO, V. J. M. Effect of soil moisture content and the irrigation frequency on the sugarcane germination. Pesquisa Agropecuária Brasileira, Brasília, DF, v. 33, n. 5, p. 721-729, maio 1998. Disponível em:

<http://seer.sct.embrapa.br/index.php/pab/article/view/4892>. Acesso em 15 maio 2015.

NASSIF, D. S. P. Parametrização e avaliação do modelo DSSAT/CANEGRO para variedades brasileiras de cana-de-açúcar. 2010. 92f. Dissertação (Mestrado) - Escola Superior de Agricultura "Luiz de Queiroz", Universidade de São Paulo, Piracicaba, 2010.

OLIVEIRA, E. C. A; FREIRE, J.F.; OLIVEIRA, A.C.; SIMÕES NETO, D.E.; ROCHA, A.T.; CARVALHO, L. A. Produtividade, eficiência de uso da água e qualidade tecnológica de cana-deaçúcar submetida a diferentes regimes hídricos. Pesquisa Agropecuária Brasileira, Brasília, DF, v.46, n.6, p.617-625, 2011

PIMENTEL, C. A relação da planta com a água. Seropédica: Edur, 2004. 191p.

R DEVELOPMENT CORE TEAM. R: A language and environment for statistical computing. R Foundation for Statistical Computing. Vienna, 2011. Disponível em: 〈http://www.R-project.org/>.

SILVA, M. de A.; SILVA, J.A.G.da; ENCISO, J.; SHARMA, V.; JIFON, J. Yield components as indicators of drought tolerance of sugarcane. Scientia Agricola, Piracicaba, v.65, n.6, p.620-627, 2008a.

SILVA, M. de A.; SOARES, R.A.B.; LANDELL, M.G. de A.; CAMPANA, M.P. Agronomic performance of sugarcane families in response to water stress. Revista Bragantia, Campinas, v.67, n.3, p.655-661, 2008b.

STOLF, R. Metodologia de avaliação de falhas nas linhas de cana-de-açúcar. STAB - Açúcar, Álcool e Subprodutos, Piracicaba, v. 4, n. 6, p. 22-36, 1986.

TAIZ, L.; ZEIGER, E. Fisiologia vegetal. Porto Alegre: Artmed, 2004. 719p.

TRENTIN, R ZOLNIER, S., RIBEIRO, S.; STEIDLE NETO, A. J. Transpiração e temperatura foliar da cana-de-açúcar sob diferentes valores de potencial matricial. Engenharia Agrícola, Jaboticabal, v. 31, n. 6, 1085-1095 2011.

TOMER, R.P.S. Better germination of cane and high yeld. Indian Sugar, New Delhi, v.18, n.10, p.765-766, 1969.

VASCONCELOS, A.C.M de; CASAGRANDE, A.A.; Fisiologia do sistema radicular. In: DINARDO-MIRANDA, L.L.; VASCONCELOS, A.C.M. de; LANDELL, M.G.A. (Ed.). Cana-deAçúcar. Campinas: IAC, 2010. p. 79-98.

VAN GENUCHTEN, M.T. A closed form equation for predicting the hydraulic conductivity of unsaturated soils. Soil Science Society of America Journal, Madison, v.44, p.892-898, 1980. 